\title{
RAD9B wt Allele
}

National Cancer Institute

\section{Source}

National Cancer Institute. RAD9B wt Allele. NCI Thesaurus. Code C106281.

Human RAD9B wild-type allele is located in the vicinity of $12 \mathrm{q} 24.11$ and is approximately $30 \mathrm{~kb}$ in leng th. This allele, which encodes cell cycle checkpoint control protein RAD9B, plays a role in DNA repair-dependent cell cycle checkpoint control. 